\title{
Identification and mapping of the novel apple scab resistance gene $V d 3$
}

\author{
J.M. Soriano • S.G. Joshi • M. van Kaauwen • \\ Y. Noordijk • R. Groenwold • B. Henken • \\ W.E. van de Weg $\cdot$ H.J. Schouten
}

Received: 21 October 2008 /Revised: 10 December 2008 / Accepted: 25 January 2009/Published online: 26 February 2009

(C) The Author(s) 2009. This article is published with open access at Springerlink.com

\begin{abstract}
Apple scab, caused by the fungal pathogen Venturia inaequalis, is one of the most devastating diseases for the apple growing in temperate zones with humid springs and summers. Breeding programs around the world have been able to identify several sources of resistance, the $V f$ from Malus floribunda 821 being the most frequently used. The appearance of two new races of $V$. inaequalis (races 6 and 7) in several European countries that are able to overcome the resistance of the $V f$ gene put in evidence the necessity of the combination of different resistance genes in the same genotype (pyramiding). Here, we report the identification and mapping of a new apple scab resistance gene $(V d 3)$ from the resistant selection "1980-015-25" of the apple breeding program at Plant Research International, The Netherlands. This selection contains also the $V f$ gene and the novel $V 25$ gene for apple scab resistance. We mapped $V d 3$ on linkage group 1, $1 \mathrm{cM}$ to the south of $V f$ in repulsion phase to it. Based on pedigree analysis and resistance tests, it could be deduced that 1980-015-25 had inherited $V d 3$ from the founder "D3." This gene provides resistance to the highly virulent EU-NL-24 strain of race 7 of $V$. inaequalis capable of overcoming the resistance from $V f$ and $V g$.
\end{abstract}

JMS and SGJ contributed equally to this work

Communicated by: A. Dandekar

J.M. Soriano · S.G. Joshi • M. van Kaauwen · Y. Noordijk •

R. Groenwold · B. Henken - W.E. van de Weg •

H.J. Schouten $(\bowtie)$

Wageningen UR, Plant Breeding,

Wageningen P.O. Box, 386, 6700 AJ, The Netherlands

e-mail: henk.schouten@wur.nl

J.M. Soriano

e-mail: miguel.soriano-soriano@wur.nl
Keywords Venturia inaequalis $\cdot$ Malus $x$ domestica $\cdot$ SSR . DArT markers

\section{Introduction}

Apple scab, caused by the fungal pathogen Venturia inaequalis (Cooke) G.Wint., is one of the most devastating diseases for apples (Malus $x$ domestica Borkh) in temperate zones with humid growing seasons. Most of the commercial apple cultivars are susceptible to the disease, and growers have to spray 20-30 times with fungicides in a season. The use of resistant cultivars could reduce the cost to the growers and may also contribute to a cleaner environment and to a reduction of fungicide residuals on apples for consumers.

The most widely used apple scab resistance gene is $V f$ from Malus floribunda 821. However, in the meantime, $V$. inaequalis strains have been detected that are able to overcome the $V f$ resistance (Parisi et al. 1993). Especially in northwestern Europe, these strains are present and have spread around (Parisi et al. 2006). As a result, several orchards consisting of $V f$-cultivars have to be sprayed like orchards with susceptible cultivars (Trapman 2006). For durable resistance, several resistance genes should be accumulated (pyramiding). Fortunately, new loci, which include both major genes and quantitative trait loci (QTLs) that confer resistance to a broad spectrum of $V$. inaequalis strains, have been discovered in Malus (Calenge et al. 2004; Schmidt and Van de Weg 2005; Gessler et al. 2006; Gardiner et al. 2006). Until now, 11 major apple scab resistance genes have been mapped (Table 1). Some of them are considered as ephemeral resistance genes, acting only against a very narrow spectrum of races of $V$. inaequalis. Molecular markers linked to these genes are available (Gessler et al. 
Table 1 Major apple scab resistance genes that have been positioned on the genetic linkage map of Malus

\begin{tabular}{llrl}
\hline Gene & Source of resistance & LG & Reference $^{\text {a }}$ \\
\hline$V a$ & Antonovka PI172623 & 1 & Hemmat et al. (2003) \\
$V b$ & Hansen's baccata \#2 & 12 & Erdin et al. (2006) \\
$V b j$ & Malus baccata jackii & 2 & Gygax et al. (2004) \\
$V d$ & Durello di Forli & 10 & Tartarini et al. (2004) \\
$V f$ & Malus floribunda 821 & 1 & Maliepaard et al. (1998) \\
$V g$ & Golden Delicious & 12 & Durel et al. (2000) \\
$V h 2$ & Malus pumila R12740-7A & 2 & Bus et al (2005a) \\
$V h 4$ & Malus pumila R12740-7A & 2 & Bus et al (2005a) \\
$V h 8$ & Malus sieversii & 2 & Bus et al (2005b) \\
$V m$ & Malus pumila R12740-7A & 17 & Patocchi et al. (2005) \\
$V r 2$ & GMAL 2473 & 2 & Patocchi et al. (2004) \\
\hline
\end{tabular}

${ }^{\mathrm{a}}$ First report of the map position

2006), and in this context, marker-assisted selection could be a useful tool in order to accelerate the breeding programs, for example, selecting the parents for the future crosses.

In this work, we report the identification and mapping of a new qualitative apple scab resistance gene named $V d 3$ from the selection "1980-015-25" of the apple breeding program of Plant Research International in Wageningen, the Netherlands. This gene provides resistance to the highly virulent EU-NL-24 strain of race 7 of $V$. inaequalis, which has overcome the resistance from $V f$ and $V g$.

\section{Material and methods}

Plant material and DNA extraction

For the mapping of $V d 3$, we used the population 2000-012C (Table 2). This population is a part of the population 2000012 comprising 894 individuals and derived from the cross between the scab-resistant selection "1980-015-025" and the susceptible selection "1973-001-041." In the resistance tests, the cultivars "Elstar," "Priscilla," "Gala," and "Golden Delicious"; the selections "D3," "1980-015-025," and "1973-001-041"; and some individuals of the population 2000-012 carrying only Vd3 were used. For pedigree analysis, the apple cultivars Elstar and Priscilla and the selections D3, 1972-010-33, and 1980-015-025 were tested with the simple sequence repeat (SSR) CH-Vfl. DNA extraction was performed from unfolded leaves of apple as described for the Diversity Arrays Technology (DArT) technique (Jaccoud et al. 2001) in http://www.diversityarrays.com.

\section{Evaluation of scab resistance}

Scab resistance was evaluated after tunnel tests with mist evaporation, where the four youngest leaves of six replicates of the progeny 2000-012 containing $V d 3$ only and reference cultivars (Elstar, D3, Priscilla, Gala, Golden Delicious, 1980015-025, and 1973-001-041) (Table 3) were inoculated with a monoconidial suspension of the nine different races of $V$. inaequalis $\left(10^{5}\right.$ conidia/ml) used in the disease tests (Table 3$)$. These isolates belong to the European collection of $V$. inaequalis from the "Durable Apple Resistance in Europe" project (Lespinasse et al. 2000). Plants were incubated for $48 \mathrm{~h}$ at $20^{\circ} \mathrm{C}$ and $100 \%$ relative humidity, and then transferred to a greenhouse with a relative humidity of $85-$ $90 \%$. Disease symptoms were assessed macroscopically after 14-17 days, indicating the presence (susceptible plant) or absence (resistant plant) of sporulation.

The population $2000-012 \mathrm{C}$ was inoculated a few weeks after emergence of the young seedlings. For mapping purposes, the strain EU-NL-24 was used. V25 confers resistance to this strain. This hampered mapping of the other resistance gene, i.e., $V d 3$. Therefore, the 143 plants that contained $V 25$ were discarded based on flanking markers of $V 25$. The remaining 92 plants were used for mapping $V d 3$. EU-NL-24 is capable of overcoming the $V f$ gene (Parisi et al 2004) and combines the virulences of races 6 and 7 (Calenge et al. 2004). Disease symptoms were assessed macroscopically after 14-17 days and rated in eight classes indicating the amount of sporulation as follows: class $0,0 \%$ of sporulation; class $1,1-2 \%$ sporulation; class $2,2-5 \%$ sporulation; class $3,5-$ $10 \%$ sporulation; class $4,10-25 \%$ sporulation; class $5,25-50 \%$ sporulation; class 6, 50-75\% sporulation; class 7, 75-100\% sporulation. This scale is similar to that reported by Durel et al. (2003), which was adapted from Croxall et al. (1952). The two youngest inoculated leaves were scored for sporulation.

\section{DArT markers}

DArT markers were produced by Diversity Arrays Technology (Yarralumla, Australia) as described in Wenzl et al. (2004) and Wittenberg et al. (2005).

Table 2 The segregating population $2000-012 \mathrm{C}$ used in this study

\begin{tabular}{lllllll}
\hline Resistance donor & Cross date & Evaluation date & $N$ & Resistance/susceptible & $\chi^{2}(p$ value $)$ mono ratio & $\chi^{2}(p$ value $)$ di ratio \\
\hline $1980-015-025$ & 2000 & 2006 & 92 & $41 / 51$ & $1.08(0.30)$ & $18.71(0.00)$ \\
\hline
\end{tabular}

${ }^{\mathrm{a}}$ Goodness of fit for monogenic inheritance

${ }^{\mathrm{b}}$ Goodness of fit for digenic inheritance 
Table 3 Strains of $V$. inaequalis used in the disease tests, and their sporulation on cultivars and selections containing $V f$, $V 25$ or $V d 3$

(R) indicates the absence or very low levels of sporulation and (S) indicates abundant sporulation. GD: Golden Delicious; 041: “1973-001-041"; 025: 1980015-025

${ }^{a}$ The resistance against these two strains is due to the $\mathrm{Vg}$ gene (Bénaouf and Parisi 2000; Parisi et al. 2004)

\begin{tabular}{|c|c|c|c|c|c|c|c|c|}
\hline \multirow[t]{2}{*}{ Strain (race) } & \multicolumn{4}{|c|}{ Without $V 25, V d 3, V f$} & \multirow{2}{*}{$\begin{array}{l}V f \\
\text { Priscilla }\end{array}$} & \multirow{2}{*}{$\begin{array}{l}V 25+V d 3+V f \\
025\end{array}$} & \multirow{2}{*}{$\begin{array}{l}V 25+V d 3 \\
\text { D3 }\end{array}$} & \multirow{2}{*}{$\begin{array}{l}V d 3 \\
2000-012\end{array}$} \\
\hline & Elstar & Gala & GD & 041 & & & & \\
\hline EU-B05 (1) & $\mathrm{S}$ & $\mathrm{S}$ & $\mathrm{S}$ & $\mathrm{S}$ & $\mathrm{R}$ & $\mathrm{R}$ & $\mathrm{R}$ & $\mathrm{S}$ \\
\hline EU-NL19 (1) & $\mathrm{S}$ & $\mathrm{S}$ & S & $\mathrm{S}$ & $\mathrm{R}$ & $\mathrm{R}$ & $\mathrm{R}$ & $\mathrm{S}$ \\
\hline $1639(2)$ & $\mathrm{S}$ & $\mathrm{S}$ & S & $\mathrm{S}$ & $\mathrm{R}$ & $\mathrm{R}$ & $\mathrm{R}$ & $\mathrm{S}$ \\
\hline US2 (3) & $\mathrm{S}$ & $\mathrm{S}$ & S & $\mathrm{S}$ & $\mathrm{R}$ & $\mathrm{R}$ & $\mathrm{R}$ & $\mathrm{S}$ \\
\hline $1638(4)$ & $\mathrm{S}$ & $\mathrm{S}$ & S & $\mathrm{S}$ & $\mathrm{R}$ & $\mathrm{R}$ & $\mathrm{R}$ & $\mathrm{S}$ \\
\hline EU-D42 (6) & $\mathrm{S}$ & $\mathrm{S}$ & S & $\mathrm{S}$ & $\mathrm{S}$ & $\mathrm{R}$ & $\mathrm{R}$ & $\mathrm{S}$ \\
\hline EU-NL05 (7) & $\mathrm{S}$ & $\mathrm{S}$ & $\mathrm{R}^{\mathrm{a}}$ & $\mathrm{S}$ & $\mathrm{S}$ & $\mathrm{R}$ & $\mathrm{R}$ & $\mathrm{S}$ \\
\hline $1066(7)$ & $\mathrm{S}$ & $\mathrm{S}$ & $\mathrm{R}^{\mathrm{a}}$ & $\mathrm{S}$ & $\mathrm{S}$ & $\mathrm{R}$ & $\mathrm{R}$ & S \\
\hline EU-NL24 (7) & $\mathrm{S}$ & $\mathrm{S}$ & $\mathrm{S}$ & $\mathrm{S}$ & $\mathrm{S}$ & $\mathrm{R}$ & $\mathrm{R}$ & $\mathrm{R}$ \\
\hline
\end{tabular}

\section{SSR markers}

All of the SSRs in linkage group (LG) 1 available at the High-quality Disease Resistant Apples for a Sustainable Agriculture (HiDRAS) database (http://www.hidras.unimi.it) were selected. In total, nine SSRs were screened in the population 2000-012C (Table 4). SSR amplifications were performed in a GeneAmp ${ }^{\circledR}$ PCR System 9700 thermal cycler (Applied Biosystems, Foster City, CA, USA) in a final volume of $20 \mu \mathrm{l}$, containing $75 \mathrm{mM}$ Tris- $\mathrm{HCl}, \mathrm{pH} \mathrm{8.8}$; $20 \mathrm{mM}\left(\mathrm{NH}_{4}\right)_{2} \mathrm{SO}_{4} ; 1.5 \mathrm{mM} \mathrm{MgCl}_{2} ; 0.2 \mathrm{mM}$ of each dNTP; $0.5 \mu \mathrm{M}$ of fluorescent dye-labeled forward primer (Hex or 6Fam, Biolegio, Nijmegen, the Netherlands); $0.5 \mu \mathrm{M}$ of reverse primer; $20 \mathrm{ng}$ of genomic DNA; and $1 \mathrm{U}$ of SuperTaq DNA polymerase (HT Biotechnology, Cambridge, UK) using the following temperature profile: $94^{\circ} \mathrm{C}$ for $2 \mathrm{~min}$ $30 \mathrm{~s}$, then 34 cycles of $94^{\circ} \mathrm{C}$ for $30 \mathrm{~s}, 50^{\circ} \mathrm{C}$ for $30 \mathrm{~s}$, and $72^{\circ} \mathrm{C}$ for $1 \mathrm{~min}$, finishing with $72^{\circ} \mathrm{C}$ for $5 \mathrm{~min}$. Samples were analyzed on an ABI PRISM 3700 DNA Analyzer (Applied Biosystems) and scored with GENOTYPER version 3.6 (Applied Biosystems).

Testing of specific markers linked to other scab resistance genes in LG1

\section{RAPD marker P-136}

The $V a$-linked RAPD marker P-136 reported by Hemmat et al. (2003) was also analyzed in the population 2000-012C to test its association with $V d 3$. RAPD amplification was performed in a GeneAmp ${ }^{\circledR}$ PCR System 9700 thermal cycler (Applied Biosystems) as described in Hemmat et al. (2003). PCR products were separated on $2 \%$ agarose gels (Hispanagar, Burgos, Spain).

Table 4. SSRs tested in 1980-015-025 parent, their position in genetic maps of Discovery (Silfverberg-Dilworth et al. 2006) and 1980-015-025, and the $\chi^{2}$ statistical analysis of the segregation for monogenic inheritance

\begin{tabular}{lllll}
\hline SSR marker & Discovery Map (cM) & $1980-015-025$ Map (cM) & $\chi^{2}$ & SSR origin \\
\hline CH03g12 & 4.2 & 0.0 & 0.19 & Liebhard et al (2002) \\
Hi21g05 & 7.6 & - & 1.35 & Silfverberg-Dilworth et al. (2006) \\
Hi02c07 & $23.1^{\text {b }}$ & - & - & Silfverberg-Dilworth et al. (2006) \\
Hi12c02 & 42.0 & 31.7 & 1.90 & Silfverberg-Dilworth et al. (2006) \\
NZ03c1 & $53.5^{\mathrm{b}}$ & - & - & Guilford et al. (1997) \\
KA4b & 42.6 & 34.4 & 0.55 & Silfverberg-Dilworth et al. (2006) \\
CH-Vf1 & 55.9 & 37.4 & 0.04 & Vinatzer et al. (2004) \\
Hi07d08 & $67.8^{\mathrm{b}}$ & - & 2.84 & Silfverberg-Dilworth et al. (2006) \\
$\mathrm{CH05g08}$ & 77.4 & 58.9 & 4.54 & Liebhard et al (2002) \\
\hline
\end{tabular}

${ }^{a}$ Monomorphic marker in population 2000-012C

${ }^{\mathrm{b}}$ Not mapped in Discovery. Position in the "Fiesta" map

${ }^{\mathrm{c}}$ Unclear pattern

${ }^{\mathrm{d}}$ Mapped in the susceptible parent (data not shown) 


\section{Vf2ARD marker}

The Vf2ARD marker developed by Boudichevskaia et al. (2008) was tested in the population 2000-012C. The PCR was performed in a GeneAmp ${ }^{\circledR}$ PCR System 9700 thermal cycler (Applied Biosystems) as described in Boudichevskaia et al. (2008). PCR products were separated on $1 \%$ agarose gels (Hispanagar).

\section{Linkage analysis}

The linkage analysis was carried out using JoinMap 4.0 software (Van Ooijen 2006) with the Kosambi mapping function (Kosambi 1944) used to convert recombination units into genetic distances. LGs were established using as threshold a minimum logarithm of odds of 6.0 and a recombination frequency lower than 0.4 . The $V d 3$ gene was mapped as a dominant gene based on the phenotype data ( 1 for resistance and 0 for susceptibility). The genetic linkage map was constructed for the resistant parent following the "two-way pseudo test-cross" model of analysis (Grattapaglia and Sederoff 1994) and setting a "cross-pollinator" data type.

\section{Results}

Evaluation of scab resistance

The population 2000-012C, segregating for $V f, V 25$, and $V d 3$, was used to evaluate the resistance against the monocodial strain of $V$. inaequalis EU-NL-24, capable of overcoming the resistance conferred by the $V f$ gene. The other strains used in the disease test overcame the resistance conferred by the $V d 3$ gene (Table 3). The resistance donor was the selection 1980-015-025, which contains the $V f$, $V 25$, and $V d 3$ genes. This selection was heterozygous for the $V d 3$ trait, and the susceptible parent was homozygous recessive. From 14 to 17 days after inoculation, plants were scored for scab resistance and classified into eight classes based on symptoms (see "Material and methods" section). As the monoconidial strain is virulent to the $V f$ resistance, two effective major resistance genes were left, i.e., V25 and $V d 3 . V 25$ and $V d 3$ inherited independently. For the purpose of mapping $V d 3$ precisely, 143 progeny plants carrying the $V 25$ gene were discarded using markers that flanked this gene tightly (unpublished data). The sporulation of the remaining seedlings $(N=92)$ is depicted in the histogram in Fig. 1. The resistance reaction observed in the plants carrying $V d 3$ was a hypersensitive pit type and chlorotic reactions.

Based on this histogram, those nonsporulating plants were designated as resistant, while those sporulating plants

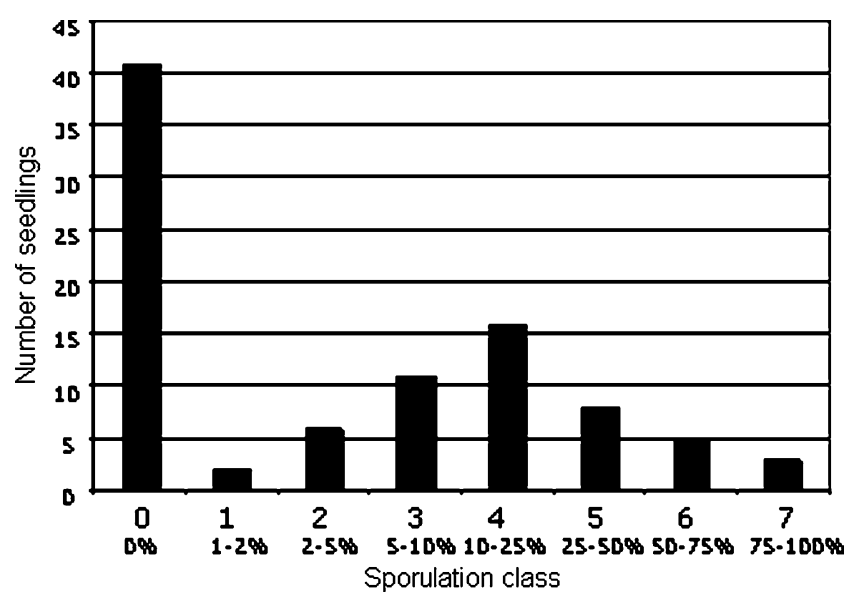

Fig. 1 Histogram showing the number of young seedlings of population 2000-012C belonging to each of the sporulation classes. The sporulation refers to percentage sporulating area in the upper two inoculated leaves

were designated as susceptible. On the basis of this scoring, 41 out of the $92 \mathrm{~F}_{1}$ individuals were considered resistant and 51 susceptible (Table 2). Segregation of resistance and susceptibility in this cross fit the ratio of $1: 1$, based on the Chi-square test $\left(\chi^{2}=1.08\right)$ using a significance level of $p$ value of 0.05 , indicating a monogenic inheritance. The hypothesis of two independent major dominant genes involved in the resistance was also tested, but it was rejected due to the high values of the Chi-square test (18.71) (Table 2).

\section{Construction of the LG1 of 1980-015-025}

This new gene could be mapped on LG1, closely to $V f$, but on the homologous chromosome, so in repulsion to the $\mathrm{CH}$ $V f$ marker (Vinatzer et al. 2004). For further mapping of $V d 3$, SSRs in LG1 were tested. Seven out of nine SSRs screened were polymorphic in the mapping population, and five of them were incorporated to the 1980-015-025 map (Table 4). In the case of the DArT markers, out of 234 markers from the resistant parent and absent in the susceptible parent, five were mapped on LG1. Other markers linked to scab resistance genes in LG1 were tested in population 2000-012C. With the first one, the RAPD marker P-136 linked to the $\mathrm{Va}$ gene according to Hemmat et al. (2003) should give the band of $700 \mathrm{bp}$, but this band was not present in the population 2000-012C (data not shown). The second marker was the marker Vf2ARD developed by Boudichevskaia et al. (2008) based on the sequence of HcrVf2 (Vinatzer et al. 2001) in the apple accessions "Antonovka," "Realka," and "Discovery." It was mapped in a similar location to the north of $V f$, as reported by these authors (Fig. 2), but the marker was also present in the susceptible parent of our population (data not shown). 


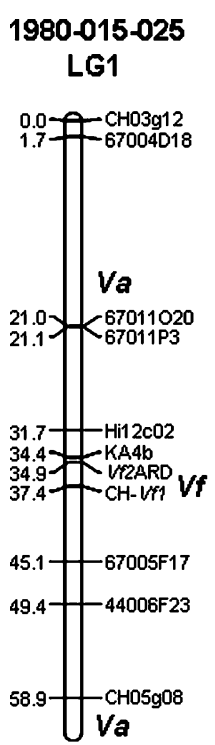

a
GPI included

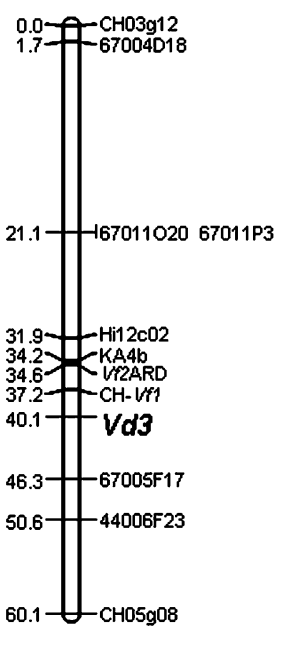

b

\section{GPI excluded}

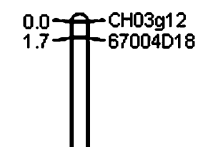

21.1- $-6701102067011 \mathrm{P3}$

Hi1 2 $\mathrm{cO2}$

34.37 KA4b

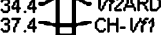

$38.47 \mathrm{CH}-\mathrm{VI}$

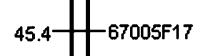

49.4-44006F 23

$59.1-\overbrace{\mathrm{CH} 05 \mathrm{gOS}}$

c
Fig. 2 Genetic maps of $V d 3$. a LG1 of 1980-015-025 showing the estimated position of $V f$ and $V a$ genes according to Gessler et al. (2006). b Map position of $V d 3$ in LG1. c Map position of $V d 3$ after removing the phenotype information of the three genotype-phenotype incongruent $(G P I)$ plants

At first, LG1 was created only with SSR and DArT markers (Fig. 2a). This map covers a distance of $58.9 \mathrm{cM}$ comprising 11 loci. The SSRs mapped maintain the colinearity with the Discovery map of SilfverbergDilworth et al. (2006) and with the "Florina" map reported by Broggini et al. (2009). Finally, $V d 3$ was mapped on LG1 as a dominant heterozygous gene, using the resistance data of the segregating population (Fig. 1). In the first location, this gene mapped between the SSR CH-Vfl and the DArT $67005 \mathrm{~F} 17$ at a distance of $2.9 \mathrm{cM}$ from the $V f$ locus (Fig. 2b). After careful observation of the resistant/ susceptible phenotype and genotype of the markers around $V d 3$, it was observed that three progeny plants (one belonging to class 1 and two to class 2) showed genotype-phenotype incongruence (GPI) (Gygax et al. 2004). These plants, classified as susceptible, showed either marker alleles in coupling with the resistance allele. In this case, by removing the resistance data of these plants, $V d 3$ was mapped again between the markers $\mathrm{CH}-V f 1$ and $67005 \mathrm{~F} 17$, but the distance to the $V f$ locus was reduced to $1.0 \mathrm{cM}$ (Fig. 2c). Exclusion of the GPI plants did not change the order of the markers, and the length of the LG1 was only reduced $0.2 \mathrm{cM}$.

Pedigree analysis of 1980-015-025 and resistance source of $V d 3$

Figure 3 shows the parents and grandparents of the selection 1980-015-025. The male parent Priscilla was used

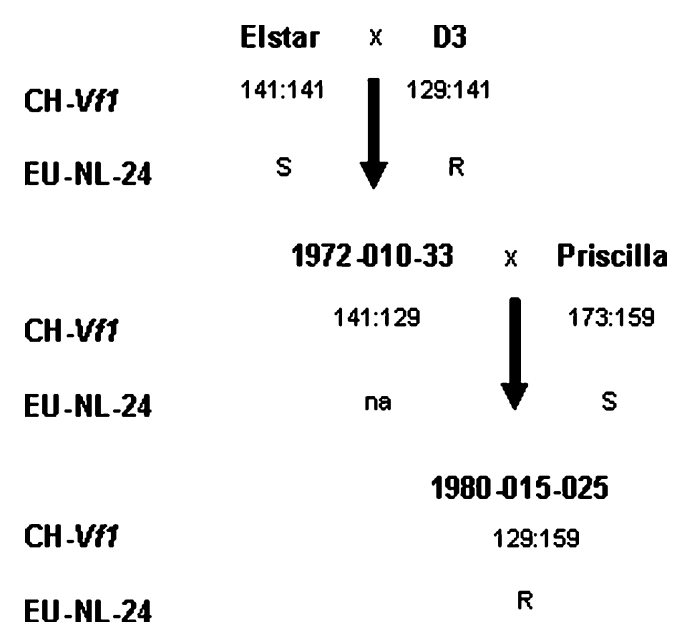

Fig. 3 SSR and resistance test of the pedigree of 1980-015-025. For the SSR CH-Vfl, the numbers indicate the different alleles of the marker in base pairs and for the strain EU-NL-24. $S$ indicates the presence of sporulation and $R$ indicates the absence of sporulation. $n a$ indicates nonassessed

as donor of the $V f$ resistance. This could be confirmed with the 159-bp allele from CH-Vfl linked to HcrVf1 (Vinatzer et al. 2004). This band was only present in the $V f$ cultivar Priscilla and in 1980-015-025.

As D3 appeared to be completely resistant in the field, this founder was used by the breeders of Plant Research International as a donor of additional resistance. They crossed it with the susceptible cultivar Elstar. Elstar and Priscilla are susceptible to the strain EU-NL-24 (Table 3) and, thus, lack the $V d 3$ gene. However, D3 is resistant to EU-NL-24 (Table 3). This suggests that $V d 3$ comes from D3. This could be confirmed with the alleles of the CH-VfI SSR, as shown in Fig. 3: $V f$ cosegregates with the 159-bp band of the SSR, whereas $V d 3$ cosegretates with the 129-bp band. The latter band originates from the source of resistance D3.

\section{Discussion}

Resistance screening

The correct placement of the threshold between resistance and susceptibility is very important to determine the resistance inheritance model and the position of the resistance gene in the linkage map. The selection of the threshold used in this work was due to the degree of sporulation observed from class 1 to class 7 and the absence of $V$. inaequalis spores in class 0 (Fig. 1). Comparison with the genetic markers indicates that this threshold gives good results, apart from three seedlings with $1-5 \%$ of sporulation. This indicates that $V d 3$ usually provided complete resistance, but $3 \%$ of the seedlings showed a low level of sporulation in spite of the 
presence of $V d 3$. We did not observe any healthy plants lacking $V d 3$. This implies that we had no plants that escaped from inoculation.

\section{Linkage map}

An accurate phenotyping of the resistance/susceptible data in the progenies is essential for the correct placement of the gene of interest in the linkage map. Two positions are proposed for the $V d 3$ gene according to the inclusion or exclusion of GPI plants of the analysis (Fig. 2b, c). In both situations, the gene is mapped between the same markers, and the order of the markers in the map is not altered, but in the case of the exclusion of the GPI plants, the distance between $V d 3$ and the $V f$ locus was reduced from 2.9 to $1 \mathrm{cM}$. As was reported by other authors (Patocchi et al. 1999a; Gygax et al. 2004; Erdin et al. 2006), we found difficulties determining the correct position of $V d 3$, as the phenotypic data were not as precise as the molecular data. During the analysis of the population 2000-012C, we classified three plants (3\%) as susceptible, but the flanking marker alleles were in coupling with the resistance. One susceptible plant without $V f$ showed from $2 \%$ to $5 \%$ sporulation. As we classified 2-5\% sporulation as susceptible and absence of $V d 3$, this plant would lack both $V f$ and $V d 3$. This is the only indication of a recombination between the $V f$ locus and the $V d 3$ locus. The flanking markers confirm this recombination event around the $V f$ locus in this plant. This single plant is responsible for positioning $V d 3$ just south of $V f$, and not at the $V f$ locus itself or north of $V f$. If the sporulation of $2-5 \%$ was regarded as resistant and the presence of $V d 3$ or all of the plants in classes 1 and 2 were discarded, then $V d 3$ would have been positioned in the same bin as the $V f$ locus. We conclude that there is evidence that $V d 3$ is south of $V f$, but for a firm proof, additional observations are needed.

Patocchi et al. (1999a), during the fine mapping of the $V f$ gene, classified about $9 \%$ of the plants as resistant, but they showed the alleles in repulsion to $V f$ in the flanking markers. The exclusion of the phenotype data of these plants was necessary in the correct mapping of the gene as they demonstrated later with the map-based cloning of the $V f$ gene (Patocchi et al. 1999b). In the mapping of the $V b j$ gene, Gygax et al. (2004) found 13 resistant plants, out of a population of 173 individuals, that did not have the marker alleles in coupling with the gene and 12 susceptible ones that had them. Finally, Erdin et al. (2006), during the mapping of the $\mathrm{Vb}$ gene in the population Golden Delicious × "Hansen's baccata \#2," identified six GPI plants. After the exclusion of the resistance data of these plants, the tension that they observed in the map disappeared. Patocchi et al. (1999a) suggested two hypotheses to explain this situation; the first one is that these plants are double recombinants, and the second one is that they were wrongly classified. As reported by these authors (Patocchi et al. 1999a; Gygax et al. 2004; Erdin et al. 2006), the presence of double recombinants is quite unlikely because of the distance of the flanking markers in coupling with $V d 3$. In our case, we expect a frequency of double recombinants of $0.6 \%$ and not the $3 \%$ observed. The hypothesis of the wrong classification could be more probable supported by the fact that these plants were classified in class 1 (one plant) and class 2 (two plants), which means from $1 \%$ to $5 \%$ of sporulation. Erdin et al (2006) suggested that the presence of susceptible plants showing the marker alleles in coupling with the resistance could be because of the presence of modifiers that might reduce the effect of the resistance gene.

The presence in a small genomic region of $V d 3$, the $V f$ locus composed of 4R (resistance)-genes (HcrVf1, HcrVf2, HcrVf3, and HcrVf4) (Vinatzer et al. 2001), and the Vf2ARD (Boudichevskaia et al. 2008) could indicate the presence of a gene cluster of $V f$-like sequences. This is supported by the fact that Broggini et al. (2009) found two SSRs developed from BAC clones containing $V f$-like sequences in the vicinity of the $V f$ locus. Another cluster of R-genes against $V$. inaequalis was found by Bus et al. (2004) in LG2. This cluster comprises four major genes, as well as several race-specific QTLs (Bus et al. 2004). This grouping of $\mathrm{R}$ genes in clusters is found frequently in plants. The biological reason could be the generation of novel resistances through the unequal crossover between different genes (Hammond-Kosack and Jones 1997).

\section{$V d 3$ is a new apple scab resistance gene}

The genetic position of $V d 3$ in LG1 permitted us to show that $V d 3$ is novel compared to all of the previously identified resistance genes against $V$. inaequalis, including $V f$, Va, and Vf2ARD genes (Patocchi et al. 1999a; Hemmat et al. 2003; Boudichevskaia et al. 2008). In the case of the $V f$ gene, the resistance spectra demonstrated that $V d 3$ is not $V f$. While the $V f$ gene has a wide resistance spectrum conferring resistance to the $V$. inaequalis races 1 to $5(\mathrm{Mc}$ Hardy 1996), in our disease tests, $V d 3$ only confers resistance to the EU-NL-24 strain (race 7) capable of overcoming the resistance provided by $V f$ (Table 3 ).

Regarding the $\mathrm{Va}$ gene, although also mapped in LG1, the position is different to that reported for $V d 3$. Gessler et al. (2006) reported the positions of the $V a$ gene mapped by Zini (2005), who used the cultivar "Freedom" as the resistance donor. This cultivar is carrying the $V f$ gene and another one coming from an unspecified Antonovka clone. In the two locations reported, the $\mathrm{Va}$ gene is outside the interval between the SSRs Hi12c02 and $\mathrm{CH} 05 \mathrm{~g} 08$ and, in both cases, at a distance of about $25 \mathrm{cM}$ from $V f$ (Zini 2005). This distance is in agreement with that reported 
previously by Hemmat et al. (2003) using as resistance donor "Antonovka PI 172633." On the contrary, Vd3 is close to $V f$ (Fig. 2) and is within the region flanked by those SSRs. Using the RAPD marker P-136 described by Hemmat et al. (2003), no results were obtained (data not shown). The band of $700 \mathrm{bp}$ reported by these authors as linked to the $\mathrm{Va}$ gene was not present in the population 2000-012C. Therefore, it was not possible to test the association between P-136 and Vd3. Moreover, the reaction types of both genes indicate that they are not the same, as $\mathrm{Va}$ induces a hypersensitive pit-type reaction (Dayton and Williams 1968), whereas $V d 3$ induces a chlorosis reaction too. Finally, taking into account the pedigree analysis showed in Fig. 3, we can say that the source of $V d 3$ (D3) does not come from an Antonovka accession. The 129-bp allele coming from D3 does not occur in the Antonovka accessions tested by Vinatzer et al. (2004) or in Antonovka 34.16 (unpublished data from HiDRAS database).

Recently, Boudichevskaia et al. (2008) reported the mapping of sequences homologous to the $V f$ genes identified by Vinatzer et al. (2001) (HcrVf genes). The candidate gene $V f 2 A R D$, developed on the basis of the divergences in the sequence of the $\mathrm{C} 1$ subdomain of the HcrVf2 gene present in the apple accessions Antonovka, Realka, and Discovery, was mapped to the north of the $V f$ locus at a distance of $1.9 \mathrm{cM}$ from the marker CH-Vf1 (Boudichevskaia et al. 2008). Using the primers developed by these authors, we mapped the $V f 2 A R D$ gene in a similar location but at a distance between 2.5 and $3 \mathrm{cM}$, depending on the map (Fig. 2). So $V d 3$, which is south of the $V f$ locus, is located at a distance of about $5 \mathrm{cM}$ from $V f 2 A R D$. Moreover, this marker was also present and mapped in the susceptible parent of our population (data not shown). So, we can discard that $V d 3$ and $V f 2 A R D$ were the same gene.

Bénaouf and Parisi (2000) detected in the cross Golden Delicious $\times M$. floribunda 821, in addition to the $V f$ resistance, another locus for resistance descending from $M$. floribunda 821. They named it $V f h$, but they did not map it. According to Parisi et al. (2004), EU-NL-24 can sporulate on M. floribunda 821. This indicates that the Vfh gene is not the same as the $V d 3$ gene.

Calenge et al. (2004) mapped QTLs for scab resistance using different strains of $V$. inaequalis. They also used EUNL-24. The QTLs for EU-NL-24 were not mapped in the vicinity of the $V f$ locus in the progeny of the cross derived from Discovery, an English cultivar partially resistant to $V$. inaequalis, and "TN10-8," a partially resistant hybrid derived from "Schmidt's Antonovka PI 172632."

In conclusion, we present in this work a new apple scab resistance gene that is only $1 \mathrm{cM}$ south of the $V f$ locus. The $V$. inaequalis strain EU-NL-24 is virulent to $V f$ but avirulent to $V d 3$ cultivars. However, $V d 3$ has not been effective against the majority of other $V$. inaequalis strains we used in our disease tests. The $V d 3$ gene is south of the $V f$ locus, in contrast to previously mapped $H c r V f$-like sequences.

Acknowledgements This research was supported by Transforum, The Netherlands. JMS was funded by a Postdoctoral contract from the Fundación Española para la Ciencia y la Tecnología (FECYT), Spain. SGJ was funded by Transforum, The Netherlands.

Open Access This article is distributed under the terms of the Creative Commons Attribution Noncommercial License which permits any noncommercial use, distribution, and reproduction in any medium, provided the original author(s) and source are credited.

\section{References}

Bénaouf G, Parisi L (2000) Genetics of host-pathogen relationships between Venturia inaequalis races 6 and 7 and Malus species. Phytopathology 90:236-242

Boudichevskaia A, Flachowsky H, Dunemann F (2008) Identification and molecular analysis of candidate genes homologous to HcrVf genes for scab resistance in apple. Plant Breed. doi:10.1111/ j.1439-0523.2008.01537.x

Broggini GAL, Galli P, Parravicini G, Gianfranceschi L, Gessler C, Patocchi A (2009) HcrVf2 paralogs are present on linkage groups 1 and 6 Malus. Genome 52:129-138

Bus V, van de Weg WE, Durel CE, Gessler C, Calenge F, Parisi L, Rikkerink E, Gardiner S, Patocchi A, Meulenbroek M, Schouten H, Laurens F (2004) Delineation of a scab resistance gene cluster on linkage group 2 of apple. Acta Hort 663:57-62

Bus VGM, Rikkerink EHA, van de Weg WE, Rusholme RL Gardiner SE, Bassett HCM et al (2005a) The Vh2 and Vh4 scab resistance genes in two differential hosts derived from Russian Apple R12740-7A map to the same linkage Group of Apple. Mol Breed 15:103-116

Bus VGM, Laurens FND, van de Weg WE, Rusholme RL, Rikkerink EHA, Gardiner SE et al (2005b) The Vh8 locus of a new genefor-gene interaction between Venturia inaequalis and the wild Apple Malus sieversii is closely linked to the Vh2 locus in Malus pumila. New Phytol 166:1035-1049

Calenge F, Faure A, Goerre M, Gebhardt C, Van de Weg WE, Parisi L, Durel CE (2004) Quantitative trait loci (QTL) analysis reveals both broad-spectrum and isolate-specific QTL for scab resistance in an apple progeny challenged with eight isolates of Venturia inaequalis. Phytopathology 94:370-379

Croxall HE, Gwynne DC, Jenkins JEE (1952) The rapid assessment of apple scab on leaves. Plant Pathol 1:39-41

Dayton DF, Williams EB (1968) Independent genes in Malus for resistance to Venturia inaequalis. Proc Am Soc Hort Sci 92:89-93

Durel CE, van de Weg WE, Venisse JS, Parisi L (2000) Localization of a major gene for apple scab resistance on the European genetic map of the Prima x Fiesta cross. OILB/WPRS Bull 23:245-248

Durel CE, Parisi L, Laurens F, van de Wed WE, Liebhard R, Jourjon MF (2003) Genetic dissection of partial resistance to race 6 of Venturia inaequalis in apple. Genome 46:224-234

Erdin N, Tartarini S, Broggini GAL, Gennari F, Sansavini S, Gessler C, Patocchi A (2006) Mapping of the apple scab resistance gene Vb. Genome 49:1238-1245

Gardiner SE, Bus VGM, Rusholme RL, Chagné D, Rikkerink EHA (2006) Apple. In: Kole C (eds) Genome mapping and molecular breeding. Fruit and nuts. vol. 4. Springer, Berlin, pp 2-62

Gessler C, Patocchi A, Sansavini S, Tartarini S, Gianfranceschi L (2006) Venturia inaequalis resistance in apple. Crit Rev Plant Sci $25: 473-503$ 
Grattapaglia D, Sederoff RR (1994) Genetic linkage maps of Eucalyptus grandis and E. urophylla using a pseudotest-cross strategy and RAPD markers. Genetics 137:1121-1137

Guilford P, Prakash S, Zhu JM, Rikkerink E, Gardiner S, Bassett H, Forster R (1997) Microsatellites in Malus x domestica (apple): abundance, polymorphism and cultivar identification. Theor Appl Genet 94:249-254

Gygax M, Gianfranceschi L, Liebhard R, Kellerhals M, Gessler C, Patocchi A (2004) Molecular markers linked to the apple scab resistance gene $\mathrm{Vbj}$ derived from Malus baccata jackii. Theor Appl Genet 109:1702-1717

Hammond-Kosack KE, Jones JDG (1997) Plant disease resistance genes. Annu Rev Plant Physiol Plant Mol Biol 48:575-607

Hemmat M, Brown SK, Aldwinckle HS, Weeden NF (2003) Identification and mapping of markers for resistance to Apple scab from "Antonovka" and "Hansen"s baccata \#2". Acta Hort 622:153-161

Jaccoud D, Peng K, Feinstein D, Kilian A (2001) Diversity Arrays: a solid state technology for sequence information independent genotyping. Nucleic Acids Res 29:e25

Kosambi DD (1944) The estimation of map distance from recombination values. Ann Eugenics 12:172-175

Lespinasse Y, Durel CE, Parisi L, Laurens F, Chevalier M, Pinet C (2000) A European project: D.A.R.E.-Durable apple resistance in Europe. Acta Hort 538:197-200

Liebhard R, Gianfrancesschi L, Koller B, Ryder CD, Tarchini R, van de Weg E, Gessler C (2002) Development and characterization of 140 new microsatellites in apple (Malus $x$ domestica Borkh.). Mol Breed 10:217-241

Maliepaard C, Alston FH, van Arkel G, Brown LM, Chevreau E, Dunemann F et al (1998) Aligning male and female linkage maps of Apple (Malus pumila Mill.) using multi-allelic markers. Theor Appl Genet 97:60-73

Mc Hardy WE (1996) Inheritance of resistance to Venturia inaequalis. In: Apple scab, biology, epidemiology and management. APS, St. Paul, pp 61-103

Parisi L, Lespinasse Y, Guillaumes J, Kruger J (1993) A new race of Venturia inaequalis virulent to apples with resistance due to the Vf gene. Phytopathology 83:533-537

Parisi L, Fouillet V, Schouten HJ, Groenwold R, Laurens F, Didelot F, Evans K, Fischer C, Gennari F, Kemp H, Lateur M, Patocchi A, Thissen J, Tsipouridis C (2004) Variability of the pathogenicity of Venturia inaequalis in Europe. Acta Hort 663:107-114

Parisi L, Laurens F, Didelot F, Evans K, Fischer C, Fouillet V, Gennari F, Kemp H, Lateur M, Patocchi A, Schouten HJ, Tsipouridis C (2006) Geographical distribution of Venturia inaequalis strains virulent to the Vf gene in Europe. Bulletin-OILB/SROP 29:49-52

Patocchi A, Gianfranceschi L, Gessler C (1999a) Towards the mapbased cloning of $V f$ : fine and physical mapping of the $V f$ region. Theor Appl Genet 99:1012-1017
Patocchi A, Vinatzer BA, Gianfranceschi L, Tartarini S, Zhang HB, Sansavini S, Gessler C (1999b) Construction of a 550Kb BAC contig spanning the genomic region containing the apple scab resistance gene $V f$. Mol Gen Genet 262:884-891

Patocchi A, Bigler B, Koller B, Kellerhals M, Gessler C (2004) $\mathrm{Vr}_{2}$ : A new apple scab resistance gene. Theor Appl Genet 109:10871092

Patocchi A, Walser M, Tartarini S, Broggini GAL, Gennari F, Sansavini S, Gessler C (2005) Identification by genome scanning approach (GSA) of a microsatellite tightly associated with the apple scab resistance gene $\mathrm{Vm}$. Genome 48:630-636

Silfverberg-Dilworth E, Matasci CL, van de Weg WE, Van Kaauwen MPW, Walser M, Kodde LP, Soglio V, Gianfranceschi L, Durel CE, Costa F, Yamamoto T, Koller B, Gessler C, Patocchi A (2006) Microsatellite markers spanning the apple (Malus $x$ domestica Borkh.) genome. Tree Genet Genom 2:202-224

Schmidt H, van de Weg WE (2005) Breeding. In: Tromp J, Webster $\mathrm{AD}$, Wertheim SJ (eds) Fundamentals of temperate zone tree fruit production. Backhuys, Leiden, pp 136-155

Tartarini S, Gennari F, Pratesi D, Palazzetti C, Sansavini S, Parisi L et al (2004) Characterization and genetic mapping of a major scab resistance gene from the old Italian apple cultivar 'Durello di Forí'. Acta Hort 663:129-133

Trapman M (2006) Resistance management in $V f$ resistant organic apple orchards. Bulletin OILB/SROP 29:253-257

Van Ooijen JW (2006) JoinMap ${ }^{\circledR} 4.0$, Software for the calculation of genetic linkage maps in experimental populations. Kyazma BV, Wageningen

Vinatzer BA, Patocchi A, Gianfranceschi L, Tartarini S, Zhang HB, Gessler C, Sansvini S (2001) Apple contains receptor-like genes homologous to the Cladosporium fulvum resistance gene family of tomato with a cluster of genes cosegregating with $V f$ apple scab resistance. MPMI 14:508-515

Vinatzer BA, Patocchi A, Tartarini S, Gianfranceschi L, Sansvini S, Gessler C (2004) Isolation of two microsatellite markers from $\mathrm{BAC}$ clones of the $V f$ scab resistance region and molecular characterization of scab-resistant accessions in Malus germplasm. Plant Breed 123:321-326

Wenzl P, Carling J, Kudrna D, Jaccoud D, Huttner E, Kleinhofs A, Kilian A (2004) Diversity arrays technology (DArT) for wholegenome profiling of barley. Proc Natl Acad Sci U S A 101:99159920

Wittenberg AHJ, van der Lee T, Cayla C, Kilian A, Visser RGF, Schouten HJ (2005) Validation of the high-throughput marker technology DArT using the model plant Arabidopsis thaliana. Mol Gen Genom 274:30-39

Zini E (2005) Costruzione di una mappa di associazione della popolazione di melo 'Golden Delicious' x 'Freedom' e caratterizzazione del gene di resistenza Va a ticchiolatura. Ph.D. thesis, DCA-BO, Italy, $126 \mathrm{p}$ 